\title{
MODEL REGRESI LOGISTIK BINER UNTUK MENENTUKAN FAKTOR YANG BERPENGARUH TERHADAP ANAK PUTUS SEKOLAH DI SULAWESI TENGAH
}

\author{
N. D. Sinaga ${ }^{1}$, Rais ${ }^{2}$, dan H. Sain ${ }^{3}$ \\ 1Program Studi Matematika Jurusan Matematika FMIPA Universitas Tadulako \\ 2,3 Program Studi Statistik Jurusan Matematika FMIPA Universitas Tadulako \\ Jalan Soekarno-Hatta Km. 9 Palu 94118, Indonesia \\ 1vitha_imoet28@yahoo.com, 2rais76_untad@yahoo.co.id, 3hartayunisain@yahoo.com
}

\section{ABSTRACT}

Education is one of the most important for the development of nations. This research aims to understand the factors that cause child could not continue school in central sulawesi using methods logistic regression binary. In this study using one variable that is free of school dropouts $(y)$. Variable not free to be researched is the type of sex $\left(X_{1}\right)$, age $\left(X_{2}\right)$, the number of household members $\left(X_{3}\right)$, educational attainment of household heads $\left(X_{4}\right)$, the schools $\left(X_{5}\right)$, and residence $\left(X_{6}\right)$. The regression analysis shows that the logistic binary of six variables are not free however, only five variable are significant. Five variables such is the variable the sex $\left(X_{1}\right)$, age $\left(X_{2}\right)$, the number of household members $\left(X_{3}\right)$, educational attainment of household heads $\left(X_{4}\right)$, and residence $\left(X_{6}\right)$. Logistic regression analysis binary used to find out the influence of the independent variable one or more $(x)$ against one the dependent variable for $(y)$. Logistic regression binary with the functioning of logit produced is :

$$
\pi(x)=\frac{e^{-11.554-0.638 x_{1}+0.651 x_{2}+0.497 x_{3}-2.005 x_{4}+0.629 x_{6}}}{1+e^{-11.554-0.638 x_{1}+0.651 x_{2}+0.497 x_{3}-2.005 x_{4}+0.629 x_{6}}}
$$

\section{Keywords $\quad$ : Binary, Children Dropping Out Of School, Logistic Regression}

\section{ABSTRAK}

Pendidikan merupakan salah satu aspek terpenting bagi pembangunan bangsa. Penelitian ini bertujuan untuk mengetahui faktor-faktor yang menyebabkan anak tidak dapat melanjutkan sekolah di Sulawesi Tengah menggunakan metode regresi logistik biner. Dalam penelitian ini menggunakan satu variabel bebas yaitu putus sekolah $(Y)$. Variabel tak bebas yang diteliti adalah jenis kelamin $\left(X_{1}\right)$, umur $\left(X_{2}\right)$, jumlah anggota rumah tangga $\left(X_{3}\right)$, pendidikan kepala rumah tangga $\left(X_{4}\right)$, jarak sekolah $\left(X_{5}\right)$, dan tempat tinggal $\left(X_{6}\right)$. Hasil analisis regresi logistik biner menunjukkan bahwa dari enam variabel tak bebas ternyata hanya lima variabel yang signifikan. Lima variabel tersebut adalah variabel jenis kelamin $\left(X_{1}\right)$, umur $\left(X_{2}\right)$, jumlah anggota rumah tangga $\left(X_{3}\right)$, pendidikan kepala rumah tangga $\left(X_{4}\right)$, dan tempat tinggal $\left(X_{6}\right)$. Analisis regresi logistik biner digunakan untuk 
mengetahui pengaruh satu variabel independen atau lebih $(\mathrm{X})$ terhadap satu variabel dependen $(\mathrm{Y})$. Regresi logistik biner dengan fungsi logit yang dihasilkan adalah :

$$
\pi(x)=\frac{e^{-11.554-0.638 x_{1}+0.651 x_{2}+0.497 x_{3}-2.005 x_{4}+0.629 x_{6}}}{1+e^{-11.554-0.638 x_{1}+0.651 x_{2}+0.497 x_{3}-2.005 x_{4}+0.629 x_{6}}}
$$

Kata Kunci $\quad$ : Anak Putus Sekolah, Logistik Biner, Regresi

\section{PENDAHULUAN}

\subsection{Latar Belakang}

Pendidikan merupakan salah satu aspek terpenting bagi pembangunan bangsa. Hampir semua bangsa menempatkan pendidikan sebagai perioritas utama dalam program pembangunan nasional mereka. Di era globalisasi seperti saat ini pendidikan menjadi suatu kebutuhan primer. Orang-orang berlomba untuk dapat mengenyam pendidikan setinggi mungkin agar tidak tertinggal dari teknologi yang semakin canggih. Tetapi disisi lain terdapat masyarakat yang hanya dapat mengenyam pendidikan dasar, bahkan ada yang tidak dapat mengenyam pendidikan sejak tingkat dasar sekalipun.

Ada banyak faktor yang meyebabkan masyarakat tidak dapat mengenyam pendidikan atau putus sekolah seperti diantaranya kesulitan ekonomi, kurangnya niat seseorang untuk mengenyam pendidikan, kurangnya fasilitas pendidikan dan selain itu karena adanya faktor lingkungan atau pergaulan (Slameto, 1995).

Pada tahun 1984 dicanangkan wajib belajar pendidikan dasar enam tahun, dan setelah sepuluh tahun berjalan kembali dicanangkan oleh pemerintah melalui Inpres Nomor 1 Tahun 1994 ditetapkan Program Wajib Belajar Pendidikan Dasar 9 Tahun. Hal ini berarti bahwa setiap anak Indonesia yang berumur 7 s/d 15 tahun diwajibkan untuk mengikuti Pendidikan Dasar 9 Tahun sampai tamat. Harapan itu begitu besar untuk masyarakat Indonesia minimal sampai tamat sekolah menengah pertama. Jika secara jujur mengevaluasi program Wajib Belajar Pendidikan Dasar Enam Tahun yang sudah 10 tahun dicanangkan, kita masih dapat melihat masih cukup banyak masyarakat Indonesia yang belum tamat setingkat pendidikan dasar. Tujuan dari pendidikan dasar yaitu memberikan bekal kemampuan dasar kepada peserta didik untuk mengembangkan kehidupannya sebagai pribadi, anggota masyarakat, warga negara, dan anggota umat manusia, serta mempersiapkan peserta didik untuk mengikuti pendidikan menengah. Pendidikan tidak hanya cukup sampai pada tingkat dasar saja tetapi masih ada jenjang pendidikan di atasnya berupa pendidikan menengah yang harus ditempuh oleh siswa. 
Dalam penelitian ini, penulis ingin menggunakan Metode Regresi Logistik Biner untuk melihat anak putus sekolah. Metode Regresi Logistik Biner digunakan untuk melihat hubungan antara variabel tak bebas $(\mathrm{Y})$ dan variabel bebas $(\mathrm{X})$. Salah satu bagian dari regresi logoistik adalah metode regresi logistik biner (M. Tiro, 2002).

\subsection{Rumusan Masalah}

Berdasarkan latar belakang yang telah di uraikan di atas, maka rumusan masalah dalam penelitian ini adalah :

1. Faktor-faktor apa yang menyebabkan anak tidak dapat melanjutkan sekolah ?

2. Bagaimana model regresi logistik biner?

\subsection{Tujuan}

Adapun tujuan dari penelitian ini adalah sebagai berikut:

1. Mengetahui faktor-faktor yang menyebabkan anak tidak dapat melanjutkan sekolah di Sulawesi Tengah.

2. Mendapatkan model regresi logistik biner.

\subsection{Batasan Penelitian}

Penelitian ini dibatasi pada data variabel penelitian yang sudah tersedia dalam data Survei Sosial Ekonomi (Susenas) di Sulawesi Tengah pada Tahun 2012.

\section{METODE PENELITIAN}

Berikut adalah prosedur penelitian yang akan dilakukan:

1. Mulai, kemudian dilanjutkan dengan pengumpulan data.

2. Setelah pengumpulan data, dilanjutkan ke pengkategorian data.

3. Melakukan uji multikolinieritas, untuk mencari hubungan antara masing - masing variabel bebas $(\mathrm{X})$.

4. Melakukan analisis Regresi Logistik Biner secara serentak (Uji G), untuk mengetahui signifikan si parameter suatu variabel bebas terhadap variabel tak bebas, jika memenuhi maka dilanjutkan ke uji individu (Uji Wald), dan uji ini maka akan menghasilkan suatu model.

5. Uji kesesuaian model, untuk mengetahui adanya perbedaan antara hasil observasi dan hasil prediksi.

6. Hasil dan Pembahasan.

7. Kesimpulan.

8. Selesai. 


\section{HASIL DAN PEMBAHASAN}

\subsection{Hasil Penelitian}

\subsubsection{Pembentukan Model Regresi Logistik Biner}

Proses awal untuk membentuk model regresi logistik biner adalah uji multikolinieritas. Uji ini bertujuan untuk menentukan variabel-variabel yang dapat dimasukkan ke dalam sebuah model. Statistik uji yang digunakan untuk uji multikolinieritas adalah uji Chi Kuadrat (Santoso, 2000). Hasil pengujian multikolinieritas pada program SPSS 21.0 adalah sebagai berikut :

1. Hasil uji Chi Kuadrat untuk variabel Jenis Kelamin dengan variabel Umur Tabel 1 : Hasil uji Chi Kuadrat antara variabel Jenis Kelamin dengan variabel Umur

\begin{tabular}{|l|c|c|c|}
\hline & Value & Df & Asymp. Sig. (2-sided) \\
\hline Pearson Chi-Square & $6.295^{\mathrm{a}}$ & 8 & .614 \\
Likelihood Ratio & 6.297 & 8 & .614 \\
Linear-by-Linear Association & .803 & 1 & .370 \\
N of Valid Cases & 5029 & & \\
\hline
\end{tabular}

Pada tabel 1 di atas menunjukkan bahwa nilai Asymp.Sig $=0,614>0.05$. Sehingga $H_{0}$ diterima, artinya kedua variabel bebas statistik (independen). Jadi variabel jenis kelamin dan variabel umur dapat dimasukkan secara bersamaan ke dalam model regresi logistik biner.

2. Hasil uji Chi Kuadrat untuk variabel Jenis Kelamin dengan Jumlah Anggota Rumah Tangga

Tabel 2 : Hasil uji Chi Kuadrat antara variabel Jenis Kelamin dengan Jumlah Anggota Rumah Tangga

\begin{tabular}{|c|c|c|c|}
\hline & Value & Df & Asymp. Sig. (2-sided) \\
\hline Pearson Chi-Square & $.404^{\mathrm{a}}$ & 1 & .525 \\
\hline Continuity Correction ${ }^{b}$ & .367 & 1 & .545 \\
\hline Likelihood Ratio & .403 & 1 & .525 \\
\hline Fisher's Exact Test & & & \\
\hline Linear-by-Linear Association & .403 & 1 & .525 \\
\hline $\mathrm{N}$ of Valid Cases & 5029 & & \\
\hline
\end{tabular}

Pada tabel 2 di atas menunjukkan bahwa nilai Asymp.Sig $=0,525>0.05$. Sehingga $H_{0}$ diterima, artinya kedua variabel bebas statistik (Independen). Jadi variabel jenis kelamin dan variabel jumlah anggota rumah tangga dapat dimasukkan secara bersamaan kedalam model regresi logistik biner.

3. Hasil uji Chi Kuadrat untuk variabel Jenis Kelamin dengan variabel Pendidikan Kepala Rumah Tangga 
Tabel 3 : Hasil uji Chi Kuadrat antara variabel Jenis Kelamin dengan variabel Pendidikan Kepala Rumah Tangga

\begin{tabular}{|l|r|r|r|}
\hline & \multicolumn{1}{|c|}{ Value } & Df & Asymp. Sig. (2-sided) \\
\hline Pearson Chi-Square & $.377^{\mathrm{a}}$ & 1 & .539 \\
Continuity Correction $^{\mathrm{b}}$ & .314 & 1 & .575 \\
Likelihood Ratio & .377 & 1 & .539 \\
Fisher's Exact Test & & & .539 \\
Linear-by-Linear Association & .377 & 1 & \\
N of Valid Cases & 5029 & & \\
\hline
\end{tabular}

Pada tabel 3 di atas menunjukkan bahwa nilai Asymp.Sig $=0.539>0.05$. Sehingga $H_{0}$ diterima, artinya kedua variabel bebas statistik (independen). Jadi variabel jenis kelamin dan variabel pendidikan kepala rumah tangga dapat dimasukkan secara bersamaan ke dalam model regresi logistik biner.

4. Hasil uji Chi Kuadrat untuk variabel Jenis Kelamin dengan Jarak Sekolah Tabel 4 : Hasil uji Chi Kuadrat antara variabel Jenis Kelamin dengan Jarak Sekolah

\begin{tabular}{|l|r|r|r|}
\hline & \multicolumn{1}{|c|}{ Value } & Df & Asymp. Sig. (2-sided) \\
\hline Pearson Chi-Square & $.008^{\mathrm{a}}$ & 1 & .930 \\
Continuity Correction $^{\mathrm{b}}$ & .003 & 1 & .956 \\
Likelihood Ratio & .008 & 1 & .930 \\
Fisher's Exact Test & & & .930 \\
Linear-by-Linear Association & .008 & 1 & \\
N of Valid Cases & 5029 & & \\
\hline
\end{tabular}

Pada tabel 4 di atas menunjukkan bahwa nilai Asymp.Sig $=0.930>0.05$. Sehingga $H_{0}$ diterima, artinya kedua variabel bebas statistik (independen). Jadi variabel jenis kelamin dan variabel jarak sekolah dapat dimasukkan secara bersamaan ke dalam model regresi logistik biner.

5. Hasil uji Chi Kuadrat untuk variabel Jenis Kelamin dengan variabel Tempat Tinggal

Tabel 5 : Hasil uji Chi Kuadrat antara variabel Jenis Kelamin dengan Tempat Tinggal

\begin{tabular}{|l|r|r|r|}
\hline & \multicolumn{1}{|c|}{ Value } & \multicolumn{1}{|c|}{ Df } & Asymp. Sig. (2-sided) \\
\hline Pearson Chi-Square & $.049 \mathrm{a}$ & 1 & .825 \\
Continuity Correction & .035 & 1 & .852 \\
Likelihood Ratio $^{\mathrm{b}}$ & .049 & 1 & .825 \\
Fisher's Exact Test & & & .825 \\
Linear-by-Linear Association & .049 & 1 & \\
N of Valid Cases & 5029 & & \\
\hline
\end{tabular}


Pada tabel 5 di atas menunjukkan bahwa nilai Asymp.Sig $=0.825>0.05$. Sehingga $H_{0}$ diterima, artinya kedua variabel bebas statistik (independen). Jadi variabel jenis kelamin dan variabel tempat tinggal dapat dimasukkan secara bersamaan ke dalam model regresi logistik biner.

6. Hasil uji Chi Kuadrat untuk variabel Umur dengan variabel Jumlah Anggota Rumah Tangga

Tabel 6 : Hasil uji Chi Kuadrat antara variabel Umur dengan variabel Jumlah Anggota Rumah Tangga

\begin{tabular}{|l|c|c|c|}
\hline & Value & df & Asymp. Sig. (2-sided) \\
\hline Pearson Chi-Square & $6.685^{\mathrm{a}}$ & 8 & .571 \\
Likelihood Ratio & 6.744 & 8 & .564 \\
Linear-by-Linear Association & 2.252 & 1 & .133 \\
N of Valid Cases & 5029 & & \\
\hline
\end{tabular}

Pada tabel 6 di atas menunjukkan bahwa nilai Asymp.Sig $=0.571>0.05$. Sehingga $H_{0}$ diterima, artinya kedua variabel bebas statistik (independen). Jadi variabel jenis kelamin dan variabel tempat tinggal dapat dimasukkan secara bersamaan ke dalam model regresi logistik biner.

7. Hasil uji Chi Kuadrat untuk variabel Umur dengan variabel Pendidikan Kepala Rumah Tangga

Tabel $7 \quad$ : Hasil uji Chi Kuadrat antara variabel Umur dengan variabel Pendidikan Kepala Rumah Tangga

\begin{tabular}{|l|r|r|r|}
\hline & \multicolumn{1}{|c|}{ Value } & \multicolumn{1}{|c|}{ Df } & Asymp. Sig. (2-sided) \\
\hline Pearson Chi-Square & $8.039 \mathrm{a}$ & 8 & .430 \\
Likelihood Ratio & 7.872 & 8 & .446 \\
Linear-by-Linear Association & 1.284 & 1 & .257 \\
N of Valid Cases & 5029 & & \\
\hline
\end{tabular}

Pada tabel 7 di atas menunjukkan bahwa nilai Asymp.Sig $=0.430>0.05$. Sehingga $H_{0}$ diterima, artinya kedua variabel bebas statistik (independen). Jadi variabel umur dan variabel pendidikan kepala rumah tangga dapat dimasukkan secara bersamaan ke dalam model regresi logistik biner.

8. Hasil uji Chi Kuadrat untuk variabel Umur dengan variabel Jarak Sekolah Tabel 8 : Hasil uji Chi Kuadrat antara variabel Umur dengan variabel Jarak Sekolah

\begin{tabular}{|l|c|c|c|}
\hline & Value & Df & Asymp. Sig. (2-sided) \\
\hline Pearson Chi-Square & $3.711^{\mathrm{a}}$ & 8 & .882 \\
Likelihood Ratio & 3.690 & 8 & .884 \\
Linear-by-Linear Association & .269 & 1 & .604 \\
N of Valid Cases & 5029 & & \\
\hline
\end{tabular}


Pada tabel 8 di atas menunjukkan bahwa nilai Asymp.Sig $=0.882>0.05$. Sehingga $H_{0}$ diterima, artinya kedua variabel bebas statistik (independen). Jadi variabel umur dan variabel jarak sekolah dapat dimasukkan secara bersamaan ke dalam model regresi logistik biner.

9. Hasil uji Chi Kuadrat untuk variabel Umur dengan variabel Tempat Tinggal Tabel 9 : Hasil uji Chi Kuadrat antara variabel Umur dengan variabel Tempat

\begin{tabular}{|l|r|r|r|}
\hline \multicolumn{1}{|c|}{ Tinggal } & \multicolumn{1}{c|}{ Value } & \multicolumn{1}{c|}{ Df } & Asymp. Sig. (2-sided) \\
\hline Pearson Chi-Square & $13.877 \mathrm{a}$ & 8 & .085 \\
Likelihood Ratio & 13.498 & 8 & .096 \\
Linear-by-Linear Association & 4.455 & 1 & .035 \\
N of Valid Cases & 5029 & & \\
\hline
\end{tabular}

Pada tabel 9 di atas menunjukkan bahwa nilai Asymp.Sig $=0.085>0.05$. Sehingga $H_{0}$ diterima, artinya kedua variabel bebas statistik (independen). Jadi variabel umur dan variabel tempat tinggal dapat dimasukkan secara bersamaan ke dalam model regresi logistik biner.

10. Hasil uji Chi Kuadrat untuk variabel Jumlah Anggota Rumah Tangga dengan variabel Pendidikan Kepala Rumah Tangga

Tabel 10 : Hasil uji Chi Kuadrat antara variabel Jumlah Anggota Rumah Tangga dengan variabel Pendidikan Kepala Rumah Tangga

\begin{tabular}{|l|c|c|c|}
\hline & Value & df & Asymp. Sig. (2-sided) \\
\hline Pearson Chi-Square & $1.703^{\mathrm{a}}$ & 1 & .192 \\
Continuity Correction ${ }^{\mathrm{b}}$ & 1.559 & 1 & .212 \\
Likelihood Ratio & 1.725 & 1 & .189 \\
Fisher's Exact Test & & & .192 \\
Linear-by-Linear Association & 1.702 & 1 & \\
N of Valid Cases & 5029 & & \\
\hline
\end{tabular}

Pada tabel 10 di atas menunjukkan bahwa nilai Asymp.Sig $=0.192>0.05$. Sehingga $H_{0}$ diterima, artinya kedua variabel bebas statistik (independen). Jadi variabel jumlah anggota rumah tangga dan variabel pendidikan kepala rumah tangga dapat dimasukkan secara bersamaan ke dalam model regresi logistik biner.

11. Hasil uji Chi Kuadrat untuk variabel Jumlah Anggota Rumah Tangga dengan variabel Jarak Sekolah 
Tabel 11 : Hasil uji Chi Kuadrat antara variabel Jumlah Anggota Rumah Tangga dengan variabel Jarak Sekolah

\begin{tabular}{|l|c|c|c|}
\hline & Value & Df & Asymp. Sig. (2-sided) \\
\hline Pearson Chi-Square & $16.430^{\mathrm{a}}$ & 1 & .000 \\
Continuity Correction & 16.159 & 1 & .000 \\
Likelihood Ratio $^{\mathrm{b}}$ & 16.245 & 1 & .000 \\
Fisher's Exact Test & & & .000 \\
Linear-by-Linear Association & 16.427 & 1 & \\
N of Valid Cases & 5029 & & \\
\hline
\end{tabular}

Pada tabel $11 \mathrm{di}$ atas menunjukkan bahwa nilai Asymp.Sig $=0.000<0.05$. Sehingga $H_{0}$ ditolak, artinya kedua variabel tidak bebas statistik (dependen). Jadi variabel jumlah anggota rumah tangga dan variabel jarak sekolah tidak dapat dimasukkan ke dalam sebuah model regresi logistik biner yang sama (pembentukan model secara terpisah).

12. Hasil uji Chi Kuadrat untuk variabel Jumlah Anggota Rumah Tangga dengan variabel Tempat Tinggal

Tabel 12 : Hasil uji Chi Kuadrat antara variabel Jumlah Anggota Rumah Tangga dengan variabel Tempat Tinggal

\begin{tabular}{|l|c|c|c|}
\hline & Value & Df & Asymp. Sig. (2-sided) \\
\hline Pearson Chi-Square & $11.601^{\mathrm{a}}$ & 1 & .001 \\
Continuity Correction $^{\mathrm{b}}$ & 11.355 & 1 & .001 \\
Likelihood Ratio & 11.786 & 1 & .001 \\
Fisher's Exact Test & & & .001 \\
Linear-by-Linear Association & 11.599 & 1 & \\
N of Valid Cases & 5029 & & \\
\hline
\end{tabular}

Pada tabel 12 di atas menunjukkan bahwa nilai Asymp.Sig $=0.001<0.05$. Sehingga $H_{0}$ ditolak, artinya kedua variabel tidak bebas statistik (dependen). Jadi variabel jumlah anggota rumah tangga dan variabel tempat tinggal tidak dapat dimasukkan ke dalam sebuah model regresi logistik biner yang sama (pembentukan model secara terpisah).

13. Hasil uji Chi Kuadrat untuk variabel Pendidikan Kepala Rumah Tangga dengan variabel Jarak Sekolah

Tabel 13 : Hasil uji Chi Kuadrat antara variabel Pendidikan Kepala Rumah Tangga dengan variabel Jarak Sekolah

\begin{tabular}{|l|c|c|c|}
\hline & Value & Df & Asymp. Sig. (2-sided) \\
\hline Pearson Chi-Square & $.795^{\mathrm{a}}$ & 1 & .373 \\
Continuity Correction $^{\mathrm{b}}$ & .690 & 1 & .406 \\
Likelihood Ratio & .784 & 1 & .376 \\
\hline
\end{tabular}




\begin{tabular}{|l|c|c|c|}
\hline Fisher's Exact Test & & & \\
\hline Linear-by-Linear Association & .795 & 1 & .373 \\
N of Valid Cases & 5029 & & \\
\hline
\end{tabular}

Pada tabel 13 di atas menunjukkan bahwa nilai Asymp.Sig $=0.373>0.05$.

Sehingga $H_{0}$ diterima, artinya kedua variabel bebas statistik (independen). Jadi variabel jumlah anggota rumah tangga dan variabel jarak sekolah dapat dimasukkan secara bersamaan ke dalam model regresi logistik biner.

14. Hasil uji Chi Kuadrat untuk variabel Pendidikan Kepala Rumah Tangga dengan variabel Tempat Tinggal

Tabel 14 : Hasil uji Chi Kuadrat antara variabel Pendidikan Kepala Rumah Tangga dengan variabel Tempat Tinggal

\begin{tabular}{|l|c|c|c|}
\hline & Value & Df & Asymp. Sig. (2-sided) \\
\hline Pearson Chi-Square & $276.796^{\mathrm{a}}$ & 1 & .000 \\
Continuity Correction ${ }^{\mathrm{b}}$ & 274.601 & 1 & .000 \\
Likelihood Ratio & 224.628 & 1 & .000 \\
Fisher's Exact Test & & & .000 \\
Linear-by-Linear Association & 276.741 & 1 & \\
N of Valid Cases & 5029 & & \\
\hline
\end{tabular}

Pada tabel 14 di atas menunjukkan bahwa nilai Asymp.Sig $=0.000<0.05$. Sehingga $H_{0}$ ditolak, artinya kedua variabel tidak bebas statistik (dependen). Jadi variabel jumlah anggota rumah tangga dan variabel tempat tinggal tidak dapat dimasukkan ke dalam sebuah model regresi logistik biner yang sama (pembentukan model secara terpisah).

15. Hasil uji Chi Kuadrat untuk variabel Jarak Sekolah dengan variabel Tempat Tinggal

Tabel 15 : Hasil uji Chi Kuadrat antara variabel Jarak Sekolah dengan variabel Tempat Tinggal

\begin{tabular}{|c|c|c|c|}
\hline & Value & Df & Asymp. Sig. (2-sided) \\
\hline Pearson Chi-Square & $3.090^{\mathrm{a}}$ & 1 & .079 \\
\hline Continuity Correction ${ }^{b}$ & 2.953 & 1 & .086 \\
\hline Likelihood Ratio & 3.052 & 1 & .081 \\
\hline Fisher's Exact Test & & & \\
\hline Linear-by-Linear Association & 3.089 & 1 & .079 \\
\hline $\mathrm{N}$ of Valid Cases & 5029 & & \\
\hline
\end{tabular}

Pada tabel 15 di atas menunjukkan bahwa nilai Asymp.Sig $=0.079>0.05$. Sehingga $H_{0}$ diterima, artinya kedua variabel bebas statistik (independen). Jadi variabel jarak sekolah dan variabel tempat tinggal dapat dimasukkan secara bersamaan ke dalam model regresi logistik biner. 


\subsubsection{Pengujian Parameter Regresi Logistik Biner Secara Serentak}

Apabila parameter yang diuji ternyata signifikan, maka hal tersebut dapat menunjukkan bahwa model yang dibentuk tepat untuk memodelkan variabel tak bebas (Hosmer dan Lemeshow, 2000).

Hipotesis yang digunakan adalah sebagai berikut :

$H_{0}=\beta_{1}=\beta_{2}=\ldots=\beta_{p}=0$ (tidak ada pengaruh antara sekumpulan variabel bebas dengan variabel tak bebas)

$H_{1}=\beta_{k} \mp 0$, (ada pengaruh terhadap variabel bebas yang berpengaruh terhadap variabel tak bebas)

Dengan menggunakan uji rasio likelihood diperoleh hasil pengujian sebagai berikut :

Tabel 16 : Nilai Chi Square Untuk Pengujian Serentak Variabel Bebas

\begin{tabular}{|l|c|c|c|c|}
\hline \multirow{2}{*}{ Model } & Model Fitting Criteria & \multicolumn{3}{|c|}{ Likelihood Ratio Tests } \\
\cline { 2 - 5 } & -2 Log Likelihood & Chi-Square & Df & Sig. \\
\hline Intercept Only & 741.460 & & & \\
Final & 296.393 & 445.067 & 13 & .000 \\
\hline
\end{tabular}

Berdasarkan tabel 16 nilai $\mathrm{G}>X_{(d, \alpha)}^{2}=445,067>22,362$ sehingga $H_{0}$ ditolak, artinya ada hubungan antara semua variabel (nilai $G$ mengikuti dari nilai Chi-Square pada tabel di atas). Berdasarkan hal diatas maka dapat dilanjutkan ke uji individu.

\subsubsection{Pengujian Parameter Regresi Logistik Biner Secara Individu}

Uji individu dilakukan untuk mengetahui signifikan si parameter suatu variabel bebas terhadap variabel tak bebas. Pada uji ini, apabila parameter yang diuji ternyata signifikan, berarti variabel bebas tersebut berpengaruh terhadap variabel tak bebas (Hosmer dan Lemeshow, 2000).

Hipotesis yang digunakan adalah sebagai berikut :

$H_{1}: \beta_{k}=0$ (tidak ada pengaruh antara variabel independen ke $k$ terhadap variabel dependen)

$H_{0}: \beta_{k} \mp 0$ (ada pengaruh variabel independen terhadap variabel dependen)

Dengan $\mathrm{k}=1,2, \ldots, \mathrm{p}$ 
Tabel 17 : Nilai Chi-Square untuk Pengujian Individu Variabel Bebas

\begin{tabular}{|c|c|c|c|}
\hline \multirow{2}{*}{ Effect } & \multicolumn{3}{|c|}{ Likelihood Ratio Tests } \\
\cline { 2 - 4 } & Chi-Square & $\mathrm{df}$ & Sig. \\
\hline Intercept & .000 & 0 &. \\
X1 & 20.516 & 1 & .000 \\
X2 & 389.113 & 8 & .000 \\
X3 & 10.561 & 1 & .001 \\
X4 & 21.009 & 1 & .000 \\
X5 & .391 & 1 & .532 \\
X6 & 10.921 & 1 & .001 \\
\hline
\end{tabular}

Pada tabel 17 diatas, didapatkan nilai-nilai chi-square dari masing-masing variabel. dapat dilihat bahwa nilai Chi Square variabel $X_{5}<\chi_{(d b, \alpha)}^{2}=0.391<$ 3.841459 yang artinya bahwa tidak mempunyai pengaruh terhadap variabel.

\subsubsection{Uji Kesesuaian Model (Goodness of fit)}

Pengujian kesesuaian model dilakukan untuk mengetahui apakah model yang diperoleh telah sesuai atau tidak (Intan, 2013). Statistik uji yang digunakan adalah uji Pearson Chi Square dengan hipotesis sebagai berikut :

$H_{0} \quad$ : Model sesuai (tidak ada perbedaan yang nyata antara hasil observasi dengan kemungkinan hasil prediksi model)

$H_{1} \quad$ : Model tidak sesuai (ada perbedaan yang nyata antara hasil observasi dengan kemungkinan hasil prediksi model)

Tabel 18 : Uji Kesesuain Model

\begin{tabular}{|l|c|c|c|}
\hline & Chi-Square & Df & Sig. \\
\hline Pearson & 238.081 & 251 & .711 \\
Deviance & 135.369 & 251 & 1.000 \\
\hline
\end{tabular}

Berdasarkan tabel diatas bahwa nilai dari chi-square pada pearson yaitu 238,081 , dengan nilai $X_{(d, \alpha)}^{2}=X_{(251,0,05)}^{2}=2889,95$ yang artinya bahwa 238,081< 2889,95 yang berarti terima $H_{0}$ artinya model sesuai (tidak ada perbedaan yang nyata antara hasil observasi dengan kemungkinan hasil prediksi model).

\subsection{Pembahasan}

Untuk melihat hubungan secara multivariat antara variabel bebas dengan variabelvariabel tak bebas dapat dilakukan dengan melihat hasil model regresi logistik. Hubungan tersebut dijelaskan oleh Tabel 19 yang melihat hubungan variabel anak putus sekolah 
sebagai variabel tak bebas, dengan variabel-variabel seperti jenis kelamin, umur, jumlah anggota rumah tangga, pendidikan kepala rumah tangga, jarak sekolah, dan tempat tinggal sebagai variabel bebas.

Tabel 19 : Hasil Analisis Regresi Logistik Variabel Putus Sekolah dengan Variabel Jenis Kelamin, Umur, Jumlah Anggota Rumah Tangga, Pendidikan Kepala Rumah Tangga, Jarak Sekolah, dan Tempat Tinggal

Variables in the Equation

\begin{tabular}{|c|c|c|c|c|c|c|c|}
\hline & & B & S.E. & Wald & df & Sig. & $\operatorname{Exp}(B)$ \\
\hline & $\mathrm{X} 1$ & -639 & .144 & 19.654 & 1 & .000 & .528 \\
\hline & X2 & .651 & .043 & 230.978 & 1 & .000 & 1.917 \\
\hline & X3 & .491 & .155 & 9.979 & 1 & .002 & 1.634 \\
\hline Step $1^{a}$ & X4 & -1.998 & .595 & 11.293 & 1 & .001 & .136 \\
\hline & $\times 5$ & .102 & .162 & .400 & 1 & .527 & 1.108 \\
\hline & X6 & .629 & .203 & 9.620 & 1 & .002 & 1.877 \\
\hline & Constant & -11.624 & .642 & 327.822 & 1 & .000 & .000 \\
\hline
\end{tabular}

Dari hasil pengolahan data model regresi logistik diperoleh persamaan regresi sebagai berikut :

$\pi(x)=\frac{e^{-11.624-0.639 x_{1}+0.651 x_{2}+0.491 x_{3}-1.998 x_{4}+0.102 x_{5}+0.629 x_{6}}}{1+e^{-11.624-0.639 x_{1}+0.651 x_{2}+0.491 x_{3}-1.998 x_{4}+0.102 x_{5}+0.629 x_{6}}}$

Tabel 20 : Hasil Analisis Regresi Logistik Variabel Putus Sekolah Dengan Variabel Jenis Kelamin, Umur, Jumlah Anggota Rumah Tangga, Pendidikan Kepala Rumah Tangga, dan Tempat Tinggal

Variables in the Equation

\begin{tabular}{|c|c|c|c|c|c|c|c|}
\hline \multicolumn{2}{|c|}{} & B & S.E. & Wald & df & Sig. & $\operatorname{Exp}(B)$ \\
\hline \multirow{4}{*}{} & $\mathrm{X} 1$ & -.638 & .144 & 19.595 & 1 & .000 & .528 \\
\cline { 2 - 8 } & $\mathrm{X} 2$ & .651 & .043 & 231.053 & 1 & .000 & 1.918 \\
\cline { 2 - 8 } & $\mathrm{X} 3$ & .497 & .155 & 10.245 & 1 & .001 & 1.643 \\
\cline { 2 - 8 } & $\mathrm{X} 4$ & -2.005 & .594 & 11.381 & 1 & .001 & .135 \\
\cline { 2 - 8 } & $\mathrm{X} 6$ & .629 & .203 & 9.599 & 1 & .002 & 1.875 \\
\cline { 2 - 8 } & Constant & -11.554 & .632 & 334.474 & 1 & .000 & .000 \\
\hline
\end{tabular}

Dari hasil tabel 20 bahwa $x_{5}$ tidak signifikan sehingga $x_{5}$ dikeluarkan dalam persamaan diatas maka persamaan yang diperoleh adalah sebagai berikut :

$\pi(x)=\frac{e^{-11.554-0.638 x_{1}+0.651 x_{2}+0.497 x_{3}-2.005 x_{4}+0.629 x_{6}}}{1+e^{-11.554-0.638 x_{1}+0.651 x_{2}+0.497 x_{3}-2.005 x_{4}+0.629 x_{6}}}$

Untuk pengujian masing-masing variabel bebas terlihat bahwa terdapat 5 (lima) variabel yang signifikan pada derajat kepercayaan $95 \%$ berpengaruh terhadap anak putus 
sekolah yaitu umur, jumlah anggota rumah tangga, pendidikan kepala rumah tangga sedangkan variabel jarak sekolah signifikan pada derajat kepercayaan $90 \%$ untuk mempengaruhi keputusan dalam putus sekolah. Hal ini mungkin disebabkan karena meskipun jarak sekolah lebih dari $2 \mathrm{Km}$ namun sarana transportasi yang tersedia cukup memadai. Variabel jenis kelamin hanya signifikan pada tingkat $78 \%$ persen menunjukkan bahwa tidak terdapat perbedaan untuk putus sekolah baik bagi laki-laki maupun perempuan. Ini dimungkinkan bagi rumah tangga khususnya yang memiliki pendapatan kurang dari garis kemiskinan tidak mendahulukan anak putus sekolah menurut jenis kelamin.

Hasil model regresi logistik yang diperoleh terdapat 5 (lima) variabel yang dapat digunakan untuk menunjukkan hubungan antara variabel anak putus sekolah dengan variabel-variabel lainnya, dimana variabel $\mathrm{X} 5$ tidak signifikan sehingga tidak dimasukkan dalam pembahasan. Besarnya pengaruh masing-masing variabel-variabel bebas terhadap variabel tak bebas dapat dilihat dari rasio kecenderungan (odd ratio)-nya. Tabel 4.27 menjelaskan bahwa :

1. Variabel jenis kelamin (X1) dengan $\mathrm{b} 1=-0.638$ dan mempunyai odd ratio sebesar 0.528 artinya peluang untuk anak putus sekolah bagi anak laki-laki sebesar 0.528 kali lebih besar dari perempuan.

2. Variabel umur $(\mathrm{X} 2)$ dengan nilai $\mathrm{b} 2=0.651$ dan mempunyai odd ratio sebesar 1.918 artinya peluang untuk anak putus sekolah bagi umur anak 7 tahun - 15 tahun 1.918 kali.

3. Variabel jumlah anggota rumah tangga (X3) dengan nilai b3 $=0.497$ dan mempunyai odd ratio sebesar 1.643 artinya peluang untuk anak putus sekolah bagi jumlah anggota rumah tangga 4 orang sebesar 1.643 kali lebih besar dari $\leq 4$ orang.

4. Variabel pendidikan kepala rumah tangga (X4) dengan nilai b4 $=-2.005$ dan mempunyai odd ratio sebesar 0.135 artinya peluang untuk anak putus sekolah bagi pendidikan kepala rumah tangga yang tinggi ( $\geq$ SLTA) sebesar 0.135 kali lebih besar dari pendidikan kepala rumah tangga rendah $(<S L T A)$.

5. Variabel tempat tinggal $(\mathrm{X} 6)$ dengan nilai b6 $=0.629$ dan mempunyai odd ratio sebesar 1.875 artinya peluang untuk anak putus sekolah yang tinggal di perdesaan sebesar 1.875 kali lebih besar dari yang tinggal di perkotaan.

Hasil penelitian ini memperlihatkan bahwa di daerah pedesaan di provinsi sulawesi tengah yang menjadi peluang besar dalam anak putus sekolah adalah jenis kelamin, umur, jumlah anggota rumah tangga, pendidikan kepala rumah tangga dan tempat tinggal. 


\section{KESIMPULAN}

Berdasarkan pembahasan pada bab sebelumnya, dapat diambil kesimpulan sebagai berikut :

1. Faktor-faktor yang mempengaruhi anak putus sekolah adalah jenis kelamin, umur, jumlah anggota rumah tangga, pendidikan kepala rumah tangga, dan tempat tinggal.

2. Dengan menggunakan model regresi logistik dapat diprediksikan :

$\pi(x)=\frac{e^{-11.554-0.638 x_{1}+0.651 x_{2}+0.497 x_{3}-2.005 x_{4}+0.629 x_{6}}}{1+e^{-11.554-0.638 x_{1}+0.651 x_{2}+0.497 x_{3}-2.005 x_{4}+0.629 x_{6}}}$

\section{DAFTAR PUSTAKA}

[1]. Hosmer, D.W. dan Lemeshow, S. Jr., 2000, "Applied Logistic Regression", 2nd Edition, John Wiley \& Son, Inc, New York.

[2]. Intan, A., 2013, Regresi Logistik Multinomial dalam Menentukan Model Tingkat Keparahan Korban Kecelakaan Lalu Lintas di Kota Palu, Tesis, Universitas Tadulako.

[3]. Singgih, S, 2000, Latihan SPSS Statistik Parmetik, Gramedia, Jakarta.

[4]. Slameto., 1995, Belajar dan Faktor-faktor Yang Mempengaruhi, Bina Aksara, Jakarta.

[5]. Tiro, M.A dan Baharuddin llyas. 2002. Statistika Terapan. Penerbit Tarsito : Bandung. 